\title{
Herbicide evaluation for rice ${ }^{1}$
}

\author{
Lii C. Liu, Luis Almodóvar-Vega and José M. Lozano ${ }^{2}$ \\ ABSTRACT
}

Two herbicide experiments on rice were conducled at the Gurabo and Lajas Substations in 1979 and 1980. Rice cullivar Brazos was planted in $3: 1 \times 3.1 \mathrm{~m}$ plots. Herbicides butachlor [N-(butoxymethyl)-2-chloro-2',6'-diethylacetanilide], oxadiazon [2 tert-butyl-4(2,4-dichloro-s-isopropoxyphenyl)- $\Delta^{2}-1,3,4$ oxadiazolin-5-one] and propanil (3,4-dichloro-propionanilide) alone or in combination were evaluated for weed control and grain yield. Butachlor at 3.36 and $6.72 \mathrm{~kg}$ ai/ha; oxadiazon at 1.12 and $2.24 \mathrm{~kg}$ ai/ha; and propanil at $3.36,6.72$ and $13.44 \mathrm{~kg}$ ai/ha; and their mixtures gave good to excellent weed control. As a group, propanil provided a better safety margin to rice than butachlor and oxadiazon. All propanil-treated plots outyielded those of the other herbicides.

\section{INTRODUCTION}

Weeds compete with rice (Oryza sativa L.) for light, nutrients, space, water, and other growth requirements. They reduce yield and quality of rice. Losses in the United States were estimated at $15 \%$ (9). In the tropical area of Puerto Rico, our climate and edaphic conditions are most conducive to the luxuriant growth of weeds. The yield losses due to weeds would be around $25 \%$ as estimated from experimental data. Considerable intensive rice production research has been conducted in Puerto Rico in recent years $(1,2,3,4,5,6,7,8)$. The present investigation represents research efforts aimed at reducing weed-caused losses in rice. Weed control and grain yield of rice as affected by different rates of butachlor, oxadiazon and propanil alone or in combination will be summarized in this paper.

\section{MATERIALS AND METHOD}

Two herbicide experiments on rice were conducted at the Gurabo and Lajas Substations in 1979 and 1980. The Gurabo experiment was established June 26, 1979, on a Coloso clay (Fluvaquents, fine, mixed, nonacid, isohyperthermic). The experimental design was a partially balanced incomplete block design with four replications. One hundred grams of rice variety Brazos were planted in rows spaced $20 \mathrm{~cm}$ in plots $3.1 \times 3.1$ m. The initial fertilizer application was 454 grams of $15-5-10$ per plot at planting plus 113 grams of zinc sulfate. The preemergence applications of butachlor (Machete $5 \mathrm{EC}$ ) at the rates of 3.36 and $6.72 \mathrm{~kg} / \mathrm{ha}$ was made June 26,1979 , with a portable $\mathrm{CO}_{2}$ sprayer. The spray volume was

\footnotetext{
' Manuscript submitted to Editorial Board March 31, 1986.

${ }^{2}$ Plant Physiologist; Professor; and Assistant Researcher, Agricultural Experiment Station, Mayaguiez Campus, University of Puerto Rico, Rio Piedras, P. R. 00928.
} 
$374 \mathrm{~L} / \mathrm{ha}$ at a pressure of $2.41 \mathrm{~kg} / \mathrm{cm}^{2}$. The postemergence application of propanil (Stam F-34 $3 \mathrm{EC}$ ) at the rates of $3.36,6.72$ and $13.44 \mathrm{~kg} / \mathrm{ha}$ and oxadiazon (Ronstar $2 \mathrm{EC}$ ) at rates of 1.12 and $2.24 \mathrm{~kg} / \mathrm{ha}$ was made on July 11, 1979. Additional postemergence applications included the mixtures of propanil at $3.36 \mathrm{~kg} / \mathrm{ha}$ with either butachlor at $3.36 \mathrm{~kg} / \mathrm{ha}$ or oxadiazon at $1.12 \mathrm{~kg} / \mathrm{ha}$ rate. The spray volume for all postemergence application was reduced to $187 \mathrm{~L} / \mathrm{ha}$ at a pressure of $2.41 \mathrm{~kg} / \mathrm{cm}$. $^{2}$ At 45 days, $340 \mathrm{~g}$ of ammonium sulfate and $226 \mathrm{~g}$ of potassium chloride were applied to each plot. All the pesticide managements were in accordance with conventional practice as described by Vicente et al. (10). Weed control ratings and phytotoxicity evaluations were made periodically. The plastic nets were extended with wooden posts over each plot at the milk stage to prevent the damage caused by birds. The plants were harvested October 22, 1979. Rice was threshed with a gasoline powered thresher and dried to $12.5 \%$ moisture content.

The Lajas experiment was established December 26, 1979 on a Fraternidad clay classified as Udic Chromusterts, very fine, montmorillonitic, isohyperthermic. The rice cultivar Brazos was planted the same day in rows spaced at $20 \mathrm{~cm}$ in plots $3.1 \times 3.1 \mathrm{~m}$. Preemergence application of butachlor at 3.36 and $6.72 \mathrm{~kg}$ ai/ha was made December 26, 1979. A postemergence application of butachlor + propanil, each, at $3.36 \mathrm{~kg}$ ai/ ha, oxadiazon at 1.12 and $2.24 \mathrm{~kg}$ ai/ha, oxadiazon at $1.12 \mathrm{~kg}$ ai/ha + propanil at $3.36 \mathrm{~kg}$ ai/ha was made January 16,1980 . The postemergence application of propanil was done February 4, 1980. The first fertilizer application was $1.12 \mathrm{~kg}$ per plot of the formula $15-5-10$ as N-P-K. The second application was ammonium sulfate at the rate of $28 \mathrm{~kg} / \mathrm{ha}$. All pesticide managements were similar to those of the Gurabo experiment. The check plots were handweeded once February 11, 1980. The first irrigation was made December 28,1980 . The field was permanently flooded from January 31, 1980 onward. The experiments were harvested April 30, 1980.

\section{RESULTS AND DISCUSSION}

\section{GURABO EXPERIMENT}

Jungle rice [Echinochloa colonum (L.) Link.] and rice flatsedge (Cyperus iria L.) were the two major weed species present in the plots. The minor weed species present in the experimental area included spreading dayflower (Commelina diffusa Brn. f.), croton (Croton lobatus L.), purslane (Portulaca oleracea L.), niruri (Phyllanthus niruri L.), morning glory [Ipomoea tiliaceae (Willd.) Choisy], red sprangle top [Leptochloa filiformis (Lam.) Beauv.], bermuda grass [Cynodon dactylon (L.) Pers], parthenium (Parthenium hysterophorus L.), and jimsonweed (Datura stramonium 
L.). All three herbicides and their mixtures provided good to excellent weed control ratings in rice (table 1). The major problem of our concern seems to be the crop safety margin. We had observed that preemergence applications of butachlor delayed rice germination. In this experiment germination of rice in butachlor-treated plots was generally poor when compared to postemergence herbicide treatments. The germination of rice was even more affected when butachlor was applied at $6.72 \mathrm{~kg} / \mathrm{ha}$ rate. Postemergence application of oxadiazon at 1.12 and $2.24 \mathrm{~kg} / \mathrm{ha}$ rate

TABLE 1.-Herbicide treatment, weed control rate and yield of rice grown at the Gurabo and Lajas Substations

\begin{tabular}{|c|c|c|}
\hline Herlucide treatment & Weed control ${ }^{1}$ & Yield $^{2}$ \\
\hline & $\%$ & $\mathrm{~kg} / \mathrm{ha}$ \\
\hline \multicolumn{3}{|c|}{ Gurabo } \\
\hline 1. Butachlor $3.36 \mathrm{~kg} \mathrm{ni} / \mathrm{ha}$ (pre) & 83 & $2,381.3 \mathrm{c}$ \\
\hline 2. Butachlor $6.72 \mathrm{~kg}$ ai $/ \mathrm{ha}$ (pre.) & 91 & $708.5 \mathrm{~d}$ \\
\hline \multicolumn{3}{|l|}{ 3. Butachlor $3.36 \mathrm{~kg}$ ai $/ \mathrm{he}+$} \\
\hline Propanil $3.36 \mathrm{~kg}$ ai/ha (post.) & 87 & $2,775.3 \mathrm{~b}$ \\
\hline 4. Oxadiazon $1.12 \mathrm{~kg}$ ai $/ \mathrm{ha}$ (post.) & 85 & $2,833.9 \mathrm{~b}$ \\
\hline 5. Oxadiazon $2.24 \mathrm{~kg}$ ai $/ \mathrm{ha}$ (post.) & 89 & $2,194.5 \mathrm{~b}$ \\
\hline \multicolumn{3}{|l|}{ 6. Oxadiazon $1.12 \mathrm{~kg}$ ai $/ \mathrm{ha}+$} \\
\hline Propanil $3.36 \mathrm{~kg}$ ai $/ \mathrm{ha}$ (post.) & 92 & $3,681.4 \mathrm{a}$ \\
\hline 7. Propanil $3.36 \mathrm{~kg}$ ai $/ \mathrm{ha}$ (post.) & 81 & $3,951.8$ a \\
\hline 8. Propanil $6.72 \mathrm{~kg}$ ai $/ \mathrm{ha}$ (post.) & 87 & $3,237.8 \mathrm{~b}$ \\
\hline 9. Propanil $13.44 \mathrm{~kg}$ ai $/ \mathrm{ha}$ (post.) & 95 & $4,045.2 \mathrm{a}$ \\
\hline 10. Weeded check & 94 & $4,262.1 \mathrm{a}$ \\
\hline 11. Nonweeded check & 0 & $2,773.7 \mathrm{~b}$ \\
\hline \multicolumn{3}{|c|}{ Lajas } \\
\hline 1. Butachlor $3.36 \mathrm{~kg}$ ai $/$ ha (pre.) & 75 & $6,457.1 \mathrm{abc}$ \\
\hline 2. Butachlor $6.72 \mathrm{~kg}$ ai $/$ ha (pre) & 86 & $7,927.8 \mathrm{ab}$ \\
\hline \multicolumn{3}{|l|}{ 3. Butachlor $3.36 \mathrm{~kg}$ ai $/ \mathrm{ha}+$} \\
\hline Propanil $3.36 \mathrm{~kg} \mathrm{ai} / \mathrm{ha}$ (post.) & 96 & $6,818.4 \mathrm{abc}$ \\
\hline 4. Oxadiazon $1.12 \mathrm{~kg} \mathrm{ai} / \mathrm{ha}$ (post.) & 81 & $4,470.0 \mathrm{c}$ \\
\hline 5. Oxadiazon $2.24 \mathrm{~kg} \mathrm{ai} / \mathrm{ha}$ (post.) & 92 & $5,507.3 \mathrm{bc}$ \\
\hline \multicolumn{3}{|l|}{ 6. Oxadiazon $1.12 \mathrm{~kg} \mathrm{ai} / \mathrm{ha}+$} \\
\hline Propanil $3.36 \mathrm{~kg}$ ai/ha (post.) & 96 & $6,048.8$ abc \\
\hline 7. Propanil $3.36 \mathrm{~kg}$ ai/ha (post.) & 84 & $6,393.4 \mathrm{abc}$ \\
\hline \multicolumn{3}{|l|}{ 8. Propanil $6.72 \mathrm{~kg} \mathrm{ai} / \mathrm{ha}$} \\
\hline$(3.36+3.36)$ split (post.) & 94 & $8,853.7 \mathrm{a}$ \\
\hline 9. Propanil $6.72 \mathrm{~kg}$ ai $/ \mathrm{ha}$ (post.) & 89 & $6,428.1$ abc \\
\hline 10. Weeded check & 75 & $5,248.1 \mathrm{c}$ \\
\hline 11. Nonweeded check & 74 & $4,374.1 \mathrm{c}$ \\
\hline
\end{tabular}

${ }^{1}$ Weed control ratings are based on a seale of $0-100$ where, $0=$ no control; $100=$ complete control.

2 Yield data in the same column with one or more letters in common do not differ statistically $(\mathbf{P}=0.05)$. 
caused a severe burning of rice seedlings. However, this injury was later outgrown. Slight leaf tip burnings were noted with propanil at the 6.72 $\mathrm{kg} / \mathrm{ha}$ rate. Leaf tip burnings further increased as the rate of propanil was increased to $13.44 \mathrm{~kg}$ ai/ha. The high summer temperature which prevailed immediately after postemergence herbicide applications might have contributed to this burning. However, all rice plants subjected to propanil treatment recovered completely.

The highest yield was obtained in the weeded check (table 1). It was followed by propanil at $13.44 \mathrm{~kg} / \mathrm{ha}$. Propanil at $3.36 \mathrm{~kg} / \mathrm{ha}$ ranked third. The application of oxadiazon alone significantly reduced yield, but when mixed with propanil at $3.36 \mathrm{~kg} / \mathrm{ha}$ the fourth highest yield was obtained. The butachlor treatments produced the lowest yield whether alone or mixed with propanil at $3.36 \mathrm{~kg} / \mathrm{ha}$. Based on the results obtained from the Gurabo experiment, propanil was still the best herbicide for the time being. Propanil at $3.36 \mathrm{~kg} / \mathrm{ha}$ rate was not enough for good weed control as it did at higher rates. A second application of propanil at the same rate 2 weeks after the first application would have controlled the weeds left behind from the first application. If the rice field had a mixed broadleaf weed population, the application of 2,4-D or the mixture of propanil with oxadiazon would be required to give a broader spectrum of weed control.

\section{LAJAS EXPERIMENT}

The predominant weed species present in the experimental plots are listed in their decreasing order of abundance; jungle rice [Echinochloa colonum (L.) Link.], dayflower (Commelina diffusa Burn. f.), Indian jointvetch (Aeschynomene sensitiva Sw.), hemp sesbania [Sesbania exaltata (Raf.) Cory.], waterprimrose (Jussiaea linifolia Vahl.), scarlet bean (Macroptilium lathyroides L.) and five fingered morning glory [Merremia quinquefolia (L.) Hall.]. With mixtures of butachlor at $3.36 \mathrm{~kg}$ ai/ha + propanil at $3.36 \mathrm{~kg}$ ai/ha and oxadiazon at $1.12 \mathrm{~kg}$ ai $/ \mathrm{ha}+$ propanil at $3.36 \mathrm{~kg}$ ai/ha weed control was excellent (table 1). Propanil at $3.36 \mathrm{~kg}$ ai/ha alone provided good weed control. As the rate of propanil was raised to $6.72 \mathrm{~kg}$ ai $/ \mathrm{ha}$, weed control was slightly improved. The split application of propanil at $6.72 \mathrm{~kg}$ ai/ha provided better weed control than that of single application of propanil at the same rate. Either butachlor at $3.36 \mathrm{~kg}$ ai/ha or oxadiazon at $1.12 \mathrm{~kg}$ ai/ha applied alone controlled weeds only fairly. All herbicides treatments, except oxadiazon and its mixture with propanil, were safe to rice and posed no crop injury problem. Oxadiazon and its mixture caused slight leaf burnings on rice plants and the injury was later outgrown. The split application of propanil at $6.72 \mathrm{~kg}$ ai/ha produced the highest rice yield. Butachlor at $6.72 \mathrm{~kg}$ ai/ ha ranked second in yield, and butachlor at $3.36 \mathrm{~kg}$ ai $/ \mathrm{ha}+$ propanil at 
$3.36 \mathrm{~kg}$ ai/ha was the third. A single application of propanil at $6.72 \mathrm{~kg}$ ai/ha ranked fourth in yield. Butachlor at $3.36 \mathrm{~kg}$ ai/ha and oxadiazon at $1.12 \mathrm{~kg} \mathrm{ai} / \mathrm{ha}+$ propanil at $3.36 \mathrm{~kg}$ ai $/$ ha also produced good yield, which was similar to the treatments mentioned above. Oxadiazon at 1.12 and $2.24 \mathrm{~kg} \mathrm{ai} / \mathrm{ha}$ and non-weeded check yielded significantly less.

\section{RESUMEN}

En las Subestaciones de Gurabo y Lajas se establecieron experimentos con herbicidas para controlar los yerbajos del arrozal. La variedad Brazos se sembró en parcelas de $3.1 \times 3.1 \mathrm{~m}$. Los herbicidas butaclor, oxadiazon y propanil, solos o combinados, se evaluaron en cuanto a control de las malezas y efecto sobre la producción. Los 3 herbicidas y sus mezclas controlaron muy bien las malezas. El propanil proveyó un mayor margen de seguridad al arroz que los demás. En general, todos los tratamientos de propanil produjeron mejores rendimientos que los de butaclor y oxadiazon en ambas localidades.

\section{LITERATURE CITED}

1. Abruña, F, and J. Lozano, 1974. Effect of season of the year on yields of 13 varieties of rice growing in the humid region of Puerto Rico, J. Agric. Univ. P.R. 58 (1): 11-7.

2. - and $\longrightarrow, 1977$. Productivity of 25 varieties of rice grown under conditions of limited moisture, J. Agric. Univ. P.R. 61 (1): 1-5.

3. Lozano, J and F. Abruña, 1977. Effect of planting season on yields of eight short-grain varieties of rice under irrigation. J. Agric. Univ. P.R. 61 (1): 6-10.

4. — and —, 1981. Nitrogen rates in single and split applications and yield of flooded rice, J. Agric. Univ. P.R. 65 (1): 35-42.

5. — and - 1982. Effect of planting methods and seeding rates on rice yields, J. Agric. Univ. P.R. 66 (3): 194-9.

6. - - and - -1982 . Season of the year and yields of seven medium grain varieties of rice, J. Agric. Univ. P.R. 66 (3): 188-93.

7. Ramírez, C. T., F. Abruña, J. Lozano and J. Vicente-Chandler, 1975. Effect of fertilization on yields of three varieties of rice at two locations in Puerto Rico, J. Agric. Univ. P.R. 59 (1): 1-4.

8. Silva, S. and J. Vicente-Chandler, 1982. Water use by flooded rice in Puerto Rico, J. Agric. Univ, P,R. 66 (3): 81-7.

9. Smith, R. J., Jr., W. T. Flinchum and D. E. Seaman, 1977. Weed control in U.S. rice production, Agric. Handbook No. 497, USDA.

10. Vicente-Chandler, J., F. Abruña, J. M. Lozano, S. Silva, A. Rodríguez y C. T. Ramirez, 1977. Cultivo intensivo y perspectivas del arroz en Puerto Rico. Esta. Agric. Univ. P.R. Bol. 250. 